\title{
Utilizing Organic Waste (Sugarcane Bagasse and Sugarcane Leaves) as Bio Briquettes through Pyrolysis Process
}

\author{
Erwan Adi Saputro*, Mu'tasim Billah, Arieanthi Laksminingsih, Yuda Eka Mardiansyah, Rachmad \\ Ramadhan Yogaswara, Nove Kartika Erliyanti \\ Chemical Engineering Department, Universitas Pembangunan Nasional "Veteran" Surabaya, East Java, Indonesia
}

${ }^{*}$ Corresponding author

E-mail:

erwanadi.tk@upnjatim.ac.id

\begin{abstract}
The energy crisis is approaching, not only Indonesia but also all around the world. This requires technological innovation to overcome it, such as; making alternative fuels that are cheap and easy to produce. One alternative way to overcome this problem is to make alternative fuels in the form of bio briquettes by utilizing organic waste (sugarcane bagasse and sugarcane leaves). This study aims to study the effect of the ratio of leaves and bagasse as main sources and using lignin as the adhesive, to produce bio briquettes. The ratio of leaves and bagasse used in this research were (30: 70). The pyrolysis process is carried out to obtain charcoal and sieved at 30 mesh. The charcoal is then mixed with the adhesive. The ratio of the amount of lignin with a mixture of sugarcane bagasse and leaves were (10: 90); (15: 85); (20: 80); (25: 75); (30: 70), and mold. The briquettes formed dried in an oven at $105^{\circ} \mathrm{C}$ for 1 hour. The results of this study showed that the lowest calorific value was $4860 \mathrm{cal} / \mathrm{kg}$ at $10 \%$ lignin content and the highest calorific value at $25 \%$ was $5876 \mathrm{cal} / \mathrm{kg}$. The results of the analysis of the lowest moisture content $(\%)$ were at $10 \%$ lignin content of $0.0781 \%$ and the highest moisture content was $0.1387 \%$ at $25 \%$ lignin content.
\end{abstract}

Keywords: Adhesive, bio briquettes, sugarcane bagasse, sugarcane leaves.

\section{Introduction}

The consumption of oil fuels is increasing in the last decade while the supply of oil or natural gas is very limited and non-renewable. Due to the limitation of the oil and natural gas, the sustainable energy sources is an alternative way to overcome this problem (Fang et al., 2008; Oyelaran et al., 2018; Qi et al., 2017; Saputro \& Farid, 2018; Zhongyang et al., 2001). Apart from that, the production of renewable energy should concern about the environmental issue as well to avoid ecological problems (Puthikitakawiwong et al., 2007; Raju et al., 2014; Saputro et al., 2019; Saputro \& Farid, 2019).

Biomass is one of the renewable energy resources. The energy generated from biomass is cheap, environmentally friendly and simply obtained from the environment (Amalinda et al., 2020; Jamradloedluk \& Wiriyaumpaiwong, 2007; Nasution et al., 2006). The production and characteristic of bio briquettes from Agricultural Waste or Biomass have been investigating by researchers all around the world (Lunjian \& Hongguang, 2007; Qi et al., 2017; Yuliansyah et al., 2019). Pyrolysis is one of the main processes to make coal as a base for bio-briquettes (Erliyanti et al., 2015). The bio briquettes could be produced from elephant grass and wood (Onuegbu et al., 2012), rice husk (Jamradloedluk \& Wiriyaumpaiwong, 2007), corncobs (Amalinda et al., 2020), and sugarcane bagasse (Cardona et al., 2010).

Based on the dry condition, sugarcane bagasse consists of elements C (carbon) 47\%, H (hydrogen) $65 \%$, Oxygen (Oxygen) 44\%, and ash (ash) $2.5 \%$. The type of leaf used is sugarcane leaves which have

How to cite:

Saputro, E. A., Billah, M., Laksminingsih, A., Mardiansyah, Y. E., Yogaswara, R. R., \& Erliyanti, N. K. (2020). Utilizing organic waste (sugarcane bagasse and sugarcane leaves) as bio briquettes through pyrolysis process. $1^{\text {st }}$ International Conference Eco-Innovation in Science, Engineering, and Technology. NST Proceedings. pages 216-220. doi: 10.11594/nstp.2020.0534 
parallel leaf bones (Hasanuddin \& Nurdin, 2010; Nugraha, 2013). Based on that, the sugarcane bagasse is promising organic waste for bio briquettes production (Agunsoye \& Aigbodion, 2013; Garcia-Pèrez et al., 2002; Montoya et al., 2015). However, the production of bio briquettes from sugarcane bagasse and leaves seems to be limited, so this research aim is to find the best composition bio briquettes from mixed sugarcane bagasse and sugarcane leaves through the pyrolysis process based on moisture content and caloric value.

\section{Research Method}

The raw materials used in this study were sugarcane bagasse and leaves from Sugar Factory Waste in Indonesia. The research variables used in this research are the ratio of leaves and bagasse, which are (30: $70)$ and the ratio of the amount of lignin to the mixture of bagasse and sugarcane leaves are (\%) : (10:90); (15: 85); (20: 80); (25: 75); (30: 70). All experiments were carried out using 10\% $\mathrm{NaOH}$ concentration, oven drying temperature of $105^{\circ} \mathrm{C}, 1$ hour drying time, Lignin density $1.3424 \mathrm{~g} / \mathrm{Lt}$, the weight of dry bagasse were 600 grams and the weight of dry leaves was 250 grams.

The equipment used in this research is a set of pyrolysis tools connected to the temperature control indicator which functions to regulate the pyrolysis temperature. Furthermore, to mold the bio briquettes a briquette mold from a plastic pipe is used.

The research procedure is divided into two major processes. The first one is lignin production, and the other is briquettes production. In the lignin production, firstly, cutting the bagasse into small pieces with a size of \pm 0.5 to $1 \mathrm{~cm}$, then crushed to form fibers, then dried under the sun. Secondly, heating 250 grams of fiber that has been dry for 1 hour to undergo the softening process. Thirdly, the softened fiber was added with an $18 \% \mathrm{NaOH}$ solution in a ratio of $1: 4$, heated for 2 hours at $100{ }^{\circ} \mathrm{C}$ to produce lignin as an adhesive for briquettes. The obtained lignin is then separated from the cellulose by a filtering process.

The cleaned leaves and bagasse are then dried under the sun, crushed, and sieved with a size of 30 mesh. The ratio of leaves and bagasse according to the variables was mixed until homogeneous. After obtaining a homogeneous mixture in pyrolysis, the mixture of bagasse and sugarcane leaves that had been pyrolyzed was mixed with lignin according to the variables. The mixture of these variables is put into a briquette mold and then molded. Drying the briquettes in the oven at $105{ }^{\circ} \mathrm{C}$ for 1 hour.

\section{Result and Discussion}

The results obtained from this research discussed in this section. The results cover the analysis of the calorific value and moisture content according to the variation of the concentration of lignin to a mixture of bagasse and sugarcane leaves. 


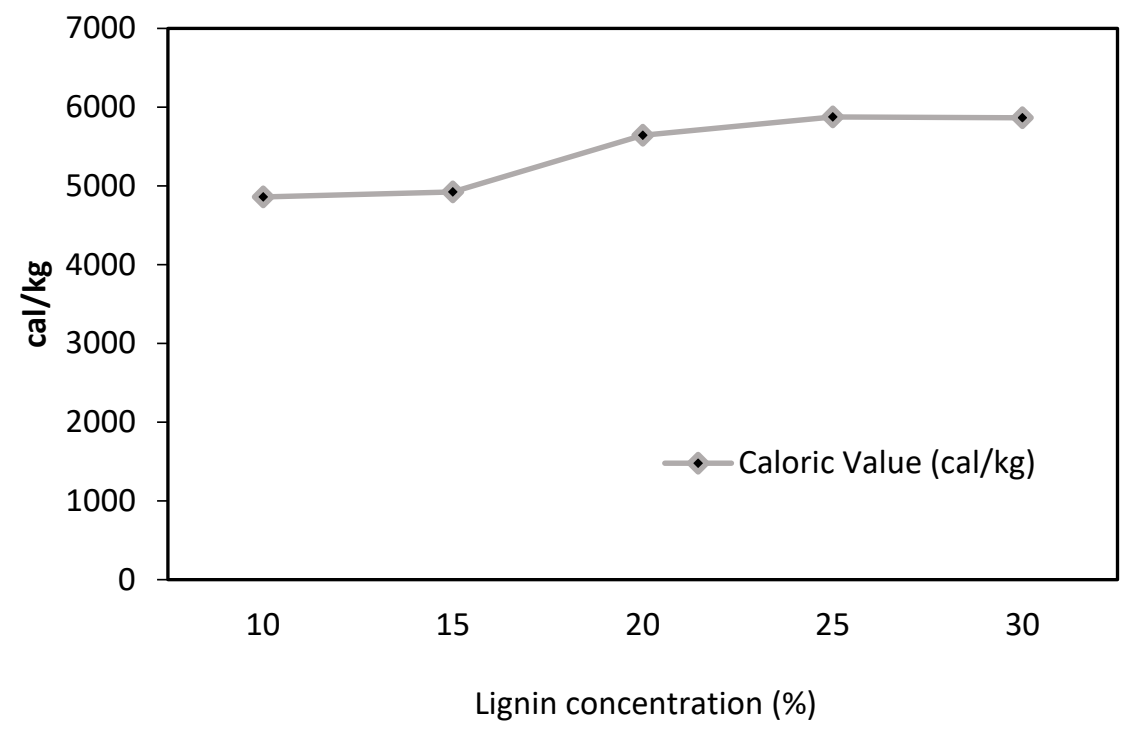

Figure 1. Lignin concentration (\%) vs caloric value

In Figure 1, it shows that the increasing lignin concentration in the mixture of pulp and sugarcane bio briquette, effect in the increased caloric value. At $10 \%$ lignin content, a low calorific value is obtained because the ratio of the mixture of bagasse and sugarcane leaves is more than lignin so that the calorific value obtained is low at $4860 \mathrm{cal} / \mathrm{kg}$. For $20 \%$ lignin, the calorific value begins to rise, and the maximum point of the highest calorific value is at $25 \%$ lignin, which is $5876 \mathrm{cal} / \mathrm{kg}$. At a lignin level of $30 \%$, the calorific value is stable because at the time of pressing lignin there is a reduction which causes the resulting calorific value to be stable with a lignin level of $25 \%$. The results of the calorific value obtained have met the requirements of the bio briquette quality standard. Coal quality standards as raw material for Coal Briquettes and coal-based solid fuels, namely a minimum heating value of $4400 \mathrm{cal} / \mathrm{kg}$. Comparing with previous researchers, who made bio briquettes but with different materials, namely the making of bio briquettes from a mixture of jatropha curcas cake (jatropha curcas l.) With husks as an alternative fuel resulted in the highest calorific value of $4320 \mathrm{cal} / \mathrm{kg}$ (Budiman et al., 2010). In the other study, bio briquettes from a ground nutshell, the highest calorific value was $2918.26 \mathrm{cal} / \mathrm{kg}$ (Akuma \& Charles, 2017). According to the highest caloric value, this research has a better caloric value among those research. 


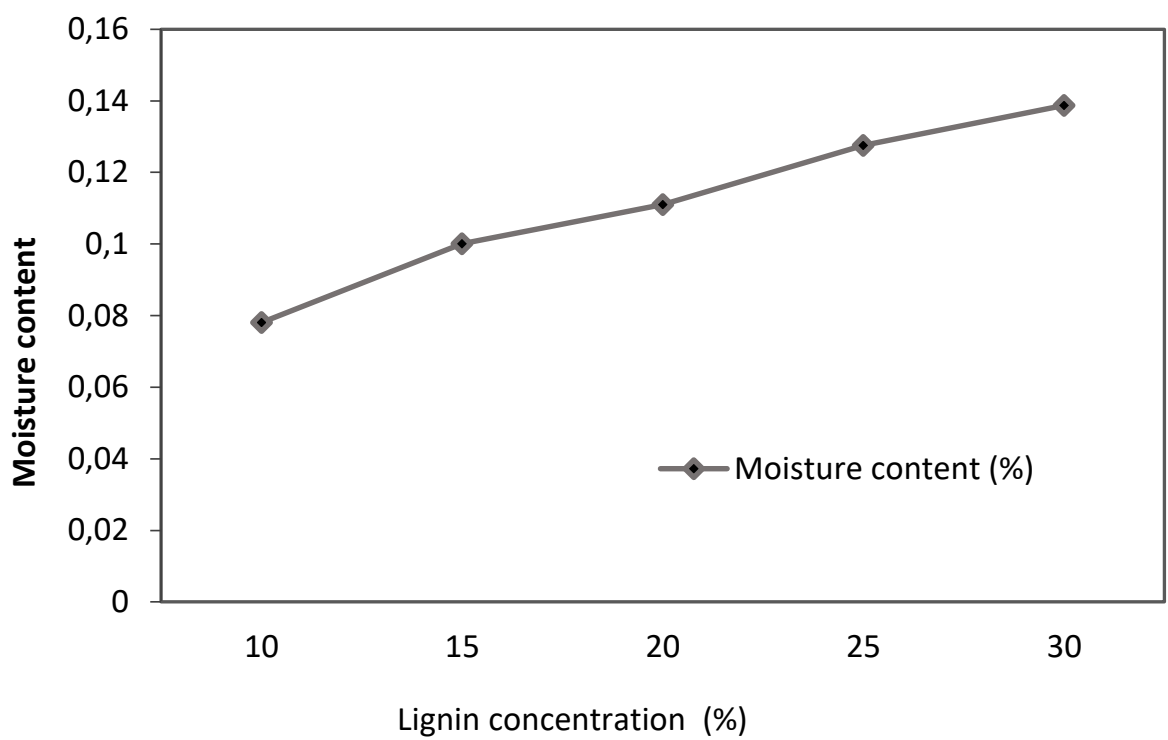

Figure 2. Lignin concentration (\%) vs moisture content (\%)

The moisture content of bio briquettes is explained in Figure 2. It shows that the higher the lignin content, the higher the moisture content. At $10 \%$ lignin content, low moisture content of $0.0781 \%$ was obtained because the lignin mixing ratio was only $10 \%$ of the mixing of ingredients. At $30 \%$ lignin content is the highest point of moisture content contained in bio briquette at $0.1387 \%$. This is because the more lignin is added to the bio briquette mixing, the less weight of the ingredients is so that the moisture content increases. With the results obtained that the moisture content at $30 \%$ is $0.1387 \%$, it has met the quality standards of coal as raw material for coal briquettes and coal-based solid fuels should have a maximum moisture content of $15 \%$.

\section{Conclusion}

Sugarcane bagasse and leaves can be used for bio briquette materials as alternative fuels without adding other adhesives because the adhesive can be derived from bagasse. When the concentration of lignin increasing, the calorific value increases as well. The lowest calorific value in this research is $4860 \mathrm{cal} / \mathrm{kg}$ at $10 \%$ lignin concentration and the highest calorific value is at $25 \%$ lignin concentration of $5876 \mathrm{cal} / \mathrm{kg}$. The lowest moisture content $(\%)$ was at $10 \%$ lignin content of $0.0781 \%$ and the highest moisture content was $0.1387 \%$ at $25 \%$ lignin concentration. Finally, this research reveals that the best composition lignin concentration for the adhesive is $25 \%$.

\section{Acknowledgment}

We would like to thank you for the technician in the research laboratory of the chemical engineering department, for their help and effort in this research.

\section{References}

Agunsoye, J. O., \& Aigbodion, V. S. (2013). Bagasse filled recycled polyethylene bio-composites: Morphological and mechanical properties study. Results in Physics, 3, 187-194.

Akuma, O., \& Charles, M. (2017). Characteristic Analysis of Bio-coal Briquette (Coal and Groundnut Shell Admixtures). International Journal of Scientific Research in Science and Technology, 2(3), 30-38.

Amalinda, F., Muliawan, A., \& Rismawati, N. (2020). The effectiveness of tabingga briquettes and corncob briquettes as biocoal. Journal of Physics: Conference Series, 1434(1). https://doi.org/10.1088/1742-6596/1434/1/012008 
Budiman, S., Sukrido, S., \& Harliana, A. (2010). Pembuatan biobriket dari campuran bungkil biji jarak pagar (Jatropha curcas L.) dengan sekam sebagai bahan bakar alternatif.

Cardona, C. A., Quintero, J. A., \& Paz, I. C. (2010). Production of bioethanol from sugarcane bagasse: status and perspectives. Bioresource Technology, 101(13), 4754-4766.

Erliyanti, N. K., Sangian, H. F., Susianto, S., \& Altway, A. (2015). The Preparation of Fixed Carbon Derived From Waste Tyre Using Pyrolysis. Scientific Study \& Research. Chemistry \& Chemical Engineering, Biotechnology, Food Industry, 16(4), 343.

Fang, L. I. U., Cheng, L. I. N., \& Rong-ying, L. I. N. (2008). Research and application of bio-coal briquette [J]. Renewable Energy Resources, 1.

Garcia-Pèrez, M., Chaala, A., \& Roy, C. (2002). Vacuum pyrolysis of sugarcane bagasse. Journal of Analytical and Applied Pyrolysis, 65(2), 111136.

Hasanuddin, H., \& Nurdin, H. (2010). Briket Ampas Tebu Sebagai Bahan Bakar Alternatif.

Jamradloedluk, J., \& Wiriyaumpaiwong, S. (2007). Production and Characterization of Rice Husk Based Charcoal Briquettes. KKU Engineering Journal, 34(August), 391-398.

Lunjian, F. A. H. G. C., \& Hongguang, J. (2007). Combustion Characteristics and Influence Factors of Bio-Briquette [J]. Coal Conversion, 3.

Montoya, J. I., Valdés, C., Chejne, F., Gómez, C. A., Blanco, A., Marrugo, G., Osorio, J., Castillo, E., Aristóbulo, J., \& Acero, J. (2015). Bio-oil production from Colombian bagasse by fast pyrolysis in a fluidized bed: An experimental study. Journal of Analytical and Applied Pyrolysis, $112,379-387$.

Nasution, R. D., Manulang, E. B., \& Erlita, Y. (2006). Pembudayaan Bahasa Inggris Pada Tingkat Sekolah Dasar di Kecamatan Patumbak Kabupaten Deli Serdang Sumatera Utara. BAHAS, 28(3).

Nugraha, J. R. (2013). Karakteristik termal briket arang ampas tebu dengan variasi bahan perekat lumpur lapindo.

Onuegbu, T. U., Ogbu, I. M., \& Ejikeme, C. (2012). Comparative Analyses of Densities and Calorific Values of Wood and Briquettes Samples Prepared At Moderate Pressure and Ambient Temperature. International Journal of Plant, Animal and Environmental Sciences, 2(1), 4045.

Oyelaran, O. A., Olorunfemi, B. J., Sanusi, O. M., Fagbemigun, A. O., \& Balogun, O. (2018). Investigating the Performance and Combustion Characteristics of Composite Bio-coal Briquette. Journal of Materials and Engineering Structures, 5, $173-184$.

Puthikitakawiwong, T., Boonsu, R., \& Joompha, O. (2007). Production of biocoal from cassava stalk. In 2004 New And Renewable Energy Technologies For Sustainable Development (pp. 165-170). World Scientific.

Qi, J., Li, Q., Wu, J., Jiang, J., Miao, Z., \& Li, D. (2017). Biocoal Briquettes Combusted in a Household Cooking Stove: Improved Thermal Efficiencies and Reduced Pollutant Emissions. Environmental Science and Technology, 51(3), 1886-1892. https://doi.org/10.1021/acs.est.6b03411

Raju, C. A. I., Jyothi, K. R., Satya, M., \& Praveena, U. (2014). Studies on development of fuel briquettes for household and industrial purpose. International Journal of Research in Engineering and Technology, 3(2), 54-63.

Saputro, E. A., Al-Shannaq, R., \& Farid, M. M. (2019). Performance of metal and non-metal coated phase change materials microcapsules when used in compressed air energy storage system. Applied Thermal Engineering, 157, 113715.

Saputro, E. A., \& Farid, M. M. (2018). A novel approach of heat recovery system in compressed air energy storage (CAES). Energy Conversion and Management, 178, 217-225.

Saputro, E. A., \& Farid, M. M. (2019). Performance of a small-scale compressed air storage (CAS). International Journal of Energy Research, 43(12), 6233-6242.

Yuliansyah, A. T., Hidayat, M., Annas, A., Putra, P. W., \& Kuswandi, C. T. (2019). Preparation and characterization of bio-coal briquettes from pyrolyzed biomass-coal blends. J. Eng. Sci. Technol, 14, 3569-3581.

Zhongyang, M. Y. L., Lin, J., Mengxiang, F., \& Kefa, C. (2001). Research On Bio Briquette Technology [J]. Coal Conversion, 1. 